\title{
Działalność Instytutu Nauk Biblijnych w roku akademickim 2017/2018
}

Academic Activity of the Institute of Biblical Studies CUL in the Year 2017/2018

\section{KS. TOMASZ BARTŁOMIEJ BĄK}

\author{
Instytut Nauk Biblijnych, Katolicki Uniwersytet Lubelski Jana Pawła \\ e-mail: tomciobak@gmail.com \\ ORCID: 0000-0003-0328-0282
}

\section{Sprawy personalne}

W roku akademickim 2017/2018 Instytut Nauk Biblijnych KUL działał w ramach czterech katedr:

\subsection{Katedra Egzegezy Ksiąg Historycznych, Prorockich i Sapiencjalnych}

Kierownik - ks. dr hab. Dariusz Dziadosz

Pracownicy:

- ks. dr hab. Andrzej Piwowar

- ks. dr Krzysztof Napora

- ks. dr Arnold Zawadzki

\subsection{Katedra Egzegezy Ewangelii i Pism Apostolskich}

Kierownik - p. dr hab. Krzysztof Mielcarek, prof. KUL

Pracownicy:

- ks. prof. dr hab. Stefan Szymik

- ks. dr Adam Kubiś

\subsection{Katedra Filologii Biblijnej i Literatury Międzytestamentalnej}

Kierownik - ks. prof. dr hab. Mirosław Wróbel 
Pracownicy:

- ks. dr hab. Henryk Drawnel, prof. KUL

- ks. dr Tomasz Bąk

\subsection{Katedra Teologii Biblijnej i Proforystyki}

Kierownik - ks. prof. dr hab. Henryk Witczyk

Pracownicy:

- ks. dr Marcin Kowalski

- ks. dr Marcin Zieliński

\section{Wydarzenia naukowe i nominacje}

7 marca 2017 r. na Zamku Lubelskim (Lublin) ks. prof. dr hab. Mirosław S. Wróbel otrzymał Nagrodę Prezydenta Miasta Lublina za publikację: Targum Neofiti 1. Księga Wyjścia. Tekst aramejski - przekład - aparat krytyczny - przypisy (Biblia Aramejska) (Lublin: Gaudium 2017).

14 kwietnia 2018 r. na Zamku Królewskim w Warszawie ks. prof. dr hab. Mirosław S. Wróbel otrzymał Nagrodę Feniksa w kategorii literackiej przyznaną przez Kapitułę Stowarzyszenia Wydawców Katolickich za publikację: Targum Neofiti 1. Ksiega Wyjścia. Tekst aramejski-przekład-aparat krytyczny-przypisy (Biblia Aramejska) (Lublin: Gaudium 2018).

Książka ks. dr. hab. Andrzeja Piwowara: Składnia języka greckiego Nowego Testamentu została nominowana przez Wydział Teologii KUL do nagrody Książka Teologiczna roku 2016.

\section{Sympozja naukowe organizowane w Instytucie Nauk Biblijnych KUL}

\subsection{Międzynarodowe Jesienne Dni Biblijne "The Dead Sea} Scrolls Seventy Years Later. Manuscripts, Traditions, Interpretations, and Their Biblical Context", KUL 24-26 października 2017 r.

Temat XIII Międzynarodowych Jesiennych Dni Biblijnych związany był z siedemdziesiątą rocznicą odkryć w Qumran. Sympozjum w znacznej mierze dotyczyło wpływu qumrańskich manuskryptów biblijnych na kształt rozumienia historii tekstu biblijnego Starego Testamentu. Wygłoszone referaty poświęcone 
były zarówno korpusowi tekstów biblijnych, jak i różnym aspektom interpretacji zwojów qumrańskich. We wtorek, 24 października, podczas dwóch seminariów naukowych o. prof. Adrian Schenker oraz prof. Emanuel Tov przedstawili również problematykę związaną z pracami nad Biblia Hebraica Quinta - nowym wydaniem tekstu hebrajskiego ST, uwzględniającego manuskrypty odkryte w Qumran.

Wśród zaproszonych gości byli m.in. uznani prelegenci z zagranicznych ośrodków naukowych: John J. Collins (Yale Divinity School, New Haven, CT, USA) Adrian Schenker OP (University of Fribourg, Switzerland) Loren T. Stuckenbruck (Ludwig Maximilian University of Munich, Germany) Eibert Tigchelaar (Katholieke Universiteit Leuven, Belgium) czy Emanuel Tov (Hebrew University, Jerusalem, Israel).

Szczegółowy program XIII Międzynarodowych Jesiennych Dni Biblijnych przedstawiał się następująco:

Wtorek, 24 października

- Adrian Schenker, O.P., University of Fribourg (Switzerland), "Problems of a Critical Edition of the Hebrew Bible in Light of the Genesis in the Biblia Hebraica Quinta".

- Emanuel Tov, Hebrew University (Jerusalem, Israel), "The Biblia Hebraica Quinta Edition of Genesis (2016)".

Środa, 25 października

Sesja I: Qumran and the Hebrew Bible

Przewodniczący: Loren Stuckenbruck (Ludwig-Maximilians-Universität, München, Germany).

- Adrian Schenker (University of Fribourg, Switzerland), "Was There a Mastercopy of a Specific Biblical Text at the Time of the Biblical Qumran Scrolls? An Investigation Into the Text History Between the 3rd and 1st Centuries".

- Emanuel Tov (Hebrew University, Jerusalem, Israel), "The Background and Origin of the Qumran Corpus of Scripture Texts".

- James M. Tucker (University of Toronto, Canada / Georg-August-Universität, Göttingen, Germany), "Scribal Error or Scribal Innovation? A Closer Look at the Law(s) of Seduction and Rape in The Temple Scroll".

- Sesja II: History and Palaeography

- Przewodniczący: Shani Tzoref (Universität Potsdam, Germany).

- John J. Collins (Yale University, New Haven, CT, USA), "The Historical Context of the Origin of the Sect Known from the Scrolls".

- Kenneth Atkinson (University of Northern Iowa, Cedar Falls, IA, USA), "The Changing Views of the Hasmoneans in the Dead Sea Scrolls: Examining Seventy Years of Research". 
- Eibert Tigchelaar (Katholieke Universiteit, Leuven, Belgium), "Seventy Years of Palaeography and Dating of the Dead Sea Scrolls".

- Sesja III: Scripture and Its Interpretation

- Przewodniczący: Jeff Anderson (Wayland Baptist University, Anchorage, AK, USA).

- John Kampen (Methodist Theological School in Ohio, Delaware, OH, USA), "Torah and Wisdom in the Rules Texts from Qumran".

- Francis Borchardt (Lutheran Theological Seminary, Hong Kong), "The Dead Sea Scrolls and How to Recognize a Scripture".

- Bartosz Adamczewski (Cardinal Stefan Wyszyński University, Warsaw, Poland), "Are the Dead Sea Scrolls Pharisaic?".

- Sesja IV: Pesher Habakkuk and Its Interpretation

- Przewodniczący: Kenneth Atkinson (University of Northern Iowa, Cedar Falls, IA, USA).

- Vasile Babota (Pontifical Gregorian University, Rome, Italy), "The Teacher of Righteousness, the Wicked Priest, and the Yahad: An Assessment of Older and More Recent Theories".

- Shani Tzoref (Universität Potsdam, Germany), Netanel Olhoeft (Universität Potsdam, Germany), "Pesher Habakkuk Through the Lenses of Medieval Jewish Peshat Exegesis: A Re-Focus".

\section{Czwartek, 26 października}

Sesja V: Enoch, Aramaic Texts, and Feminist Perspective

Przewodniczący: Francis Borchardt (Lutheran Theological Seminary, Hong Kong).

- Loren Stuckenbruck (Ludwig-Maximilians-Universität, München, Germany), "What Can the Ethiopic Tradition Contribute to Our Reconstruction of the Aramaic TextTradition of 1 Enoch?".

- Atar Livneh (Ben-Gurion University of the Negev, Beer-Sheva, Israel), "Pretty Woman: Notes on Sarah's Beauty in 1QGenAp XX 2-8".

- Claude Cohen-Matlofsky (Institut Universitaire d'Études Juives Élie Wiesel, Paris / «Séminaire Qumrân de Paris» / Laboratoire d'Études sur les Monothéismes CNRS, France), "Woman or Women at Qumran: Texts and Archaeology".

- Sesja VI: Linguistics and Performativity

- Przewodniczący: Eibert Tigchelaar (Katholieke Universiteit, Leuven, Belgium).

- Donald W. Parry (Brigham Young University, Provo, UT, USA), "Late Biblical Hebrew Forms in 1QIsa-a: A Corpus Linguistic Approach".

- Femke Siebesma-Mannens (Vrije Universiteit, Amsterdam, the Netherlands), "Qumran Hebrew from the Perspective of Verbal Valence Patterns". 
- Jeff Anderson (Wayland Baptist University, Anchorage, AK, USA), "Assembled Israel: Performativity in Rewritten Bible at Qumran".

- Sesja VII: Texts and their Interpretation

- Przewodniczący: Antoni Tronina (John Paul II Catholic University of Lublin, Poland).

- Marek Parchem (Cardinal Stefan Wyszyński University, Warsaw, Poland), "The Motif of Throne in Heavens in the Qumran Writings and the Beginnings of the Merkābāh Mysticism".

- Anna Kuśmirek (Cardinal Stefan Wyszyński University, Warsaw, Poland), "The Targums from Qumran: Their Place in the Studies on the Judean Desert Scrolls".

- Marek Baraniak (University of Warsaw, Poland), "Crux interpretum 11QPs 151,3-4 from the Perspective of the Biblical and Semitic Rhetoric Analysis".

- Mária Kardis (University of Prešov, Slovakia), "Psalm of Solomon 17 in the Light of Messianic Texts of Early Judaism".

- Sesja VIII: From Spiritual Battle to Repentance

- Przewodniczący: Atar Livneh (Ben-Gurion University of the Negev, Beer-Sheva, Israel).

- Christine Leroy (Katholieke Universiteit, Leuven, Belgium), "Spiritual Battles of the Sage: 'walking in the way of his heart'. Transformation in the Hodayot".

- Yuri A. Snisarenko (Saint Petersburg State University, Saint Petersburg, Russia), "Teshuvah in the Jewish Literature of the Second Temple Period: From Return to Repentance".

- John Francis Elwolde (Facultat d Teologia de Catalunya, Barcelona, Spain), "The human spirit and the holy spirit in the Qumran Hodayot (Thanksgiving Hymns)".

\subsection{Wiosenne Sympozjum Biblijne "Weźmijcie Ducha Świętego" (J 20,22). Duch Święty w Kościele", KUL, 20 marca 2018 r.}

Program Wiosennego Sympozjum Biblijnego, w trakcie którego wygłoszonych zostało osiem referatów, przedstawiał się następująco:

Sesja I, przewodniczący: ks. Tomasz Bąk

- ks. dr Mariusz Szmajdziński (Łowicz), „Duch udzielony Mesjaszowi w Księdze Izajasza".

- ks. dr Marcin Zieliński (KUL) - „«Przyszedł mi z pomocą Duch mądrości» (Mdr 7,7). Duch Święty jako nauczyciel mądrości”. 
- ks. dr Łukasz Łaszkiewicz (WT Uniwersytet Szczeciński), „«Za natchnieniem Ducha...» (Łk 2,17). Duch Święty jako objawiciel Mesjasza Pańskiego".

Sesja II, przewodniczący: ks. dr Marcin Kowalski

- ks. prof. dr hab. Henryk Witczyk (KUL), „Aktywność Ducha Świętego w autorze i tekście natchnionym (J 15,26-27; Ap 1,10; 4,2; 2 Tm 3,16; 2 P 1,21-21)".

- dr hab. Branislav Kluska (KU Ružomberok), „Duch Paraklet a pamięć Kościoła w ujęciu czwartej Ewangelii”.

Sesja III, przewodniczący: ks. dr hab. Andrzej Piwowar

- ks. dr Marcin Kowalski (KUL), „ «O Duchu, który w nas mieszka» (Rz 8,9). Co ma wspólnego św. Paweł ze starożytną filozofią i medycyną?”.

- ks. dr Tomasz Siemieniec (KUL), „Obietnice Ducha dla „martwych” w świetle Ap 14,13".

- ks. dr Sławomir Jeziorski (Rzeszów), „Misterium Pięćdziesiątnicy: lektura liturgiczna wydarzenia biblijnego".

\section{Działalność dydaktyczno-naukowa pracowników Instytutu Nauk Biblijnych KUL}

Prezentację działalności dydaktyczno-naukowej rozpoczyna osoba Dyrektora Instytutu Nauk Biblijnych KUL. W dalszej kolejności przyjęty został porządek alfabetyczny. Pod hasłem „Wykłady” należy rozumieć działalność dydaktyczną, wykraczającą poza obowiązkowe zajęcia, prowadzone przez pracowników Instytutu Nauk Biblijnych na KUL.

\section{1) Dyrektor Instytutu Nauk Biblijnych KUL: ks. prof. dr hab. Mirosław Stanisław Wróbel}

\section{Monografie, książki pod redakcją:}

1. Targum Neofiti 1: Księga Wyjścia. Tekst aramejski-przektad-aparat krytyczny - przypisy (Biblia Aramejska) (Lublin: Gaudium 2017).

2. Wprowadzenie do Biblii Aramejskiej (Lublin: Gaudium - KUL 2017).

3. Redakcja książki: Ks. Grzegorz Pawłowski (Jakub Hersz Griner), Kapłański testament stugi Mesjasza (Lublin: Gaudium 2017).

4. Redakcja książki: Natchnienie Pisma Świętego. W'świetle świadectwa tekstów o nich samych (Lublin: Wydawnictwo KUL 2017). 


\section{Artykuły naukowe i hasła słownikowe}

1. „Theological Concept of the Fourth Gospel in the Context of Jesus' Glorification Prayer (Jn 17,1-5)", The Person and the Challenges 7/1 (2017) 223-242.

2. „Biblia Aramejska w przekładzie na język polski jako wyzwanie do dialogu pomiędzy judaizmem i chrześcijaństwem", Svet kultúr a tradícií slovensko-pol'ského pohraničia. Zvyšovanie kompetencii vysokoškolských pedagógov v oblasti interkultúrneho vzdelávania (red. M. Kardis - K. Kardis) (Prešov: Prešovská univerzita 2017) 188-210.

3. "The Aramaic Bible as a Translation of the Word of God in the Synagogal Liturgy", Ways to Religion (ed. A.R. Knapik et al.) (Wrocław - Washington, D.C.: Wyższa Szkoła Filologiczna, Polska Akademia Nauk \& International Communicology Institute 2017) 211-226.

4. „Jezus i chrześcijanie w Talmudzie”, Historia - Wiara - Nauka. Źródła poznania Jezusa Chrystusa (red. P. Artemiuk) (Płock: Stowarzyszenie Teologów Fundamentalnych w Polsce - Płocki Instytut Wydawniczy 2018) 167-184.

5. „Znaczenie targumów w argumentacji fundamentalnoteologicznej”, Historia - Wiara - Nauka. Źródła poznania Jezusa Chrystusa (red. P. Artemiuk) (Płock: Stowarzyszenie Teologów Fundamentalnych w Polsce - Płocki Instytut Wydawniczy 2018) 185-202.

6. „Naród wybrany”, Nowy Stownik Teologii Biblijnej (red. H. Witczyk) (Lublin - Kielce: Towarzystwo Naukowe KUL - Jedność, 2017) 602-604.

7. „Pięćdziesiątnica”, NSTB, 695-698.

8. „Szabat”, NSTB, 855-856.

9. „Zly”, NSTB, 1001.

\section{Artykuły popularnonaukowe:}

1. „Duchowość wspólnoty z Qumran”, Biblia krokpo kroku nr 9 (55) (2017) 15-20.

2. „Księga Daniela - nazwa, treść i orędzie teologiczne”, Krag Biblijny nr 33. Materiały dla duszpasterzy, animatorów $i$ wszystkich, którzy pragna czytać Pismo Święte (Tarnów: Wydawnictwo Biblos 2017) 119-122.

3. „Postać Syna Człowieczego w Ewangelii Janowej”, Krag Biblijny nr 33. Materiaty dla duszpasterzy, animatorów $i$ wszystkich, którzy pragna czytać Pismo Święte (Tarnów: Wydawnictwo Biblos 2017) 122-126.

4. „Księga Ozeasza - nazwa, treść i orędzie teologiczne”, Krag Biblijny nr 34. Materiaty dla duszpasterzy, animatorów $i$ wszystkich, którzy pragna czytać Pismo Święte (Tarnów: Wydawnictwo Biblos 2017) 119-122. 
5. „Wewnętrzne problemy Izraela ukazane w Księdze Ozeasza”, Krą Biblijny $n r$ 34. Materialy dla duszpasterzy, animatorów i wszystkich, którzy pragna czytać Pismo Święte (Tarnów: Wydawnictwo Biblos 2017) 123-127.

6. „Księga Joela - nazwa, treść i orędzie teologiczne”, Krag Biblijny nr 35. Materiaty dla duszpasterzy, animatorów i wszystkich, którzy pragna czytać Pismo Święte (Tarnów: Wydawnictwo Biblos 2017) 125-128.

7. „Znaki końca czasów w Księdze Joela w kontekście Starego i Nowego Testamentu", Krag Biblijny nr 35. Materiaty dla duszpasterzy, animatorów $i$ wszystkich, którzy pragna czytać Pismo Święte (Tarnów: Wydawnictwo Biblos 2017) 129-133.

8. „Księga Amosa - nazwa, treść i orędzie teologiczne”, Krąg Biblijny nr 36. Materiały dla duszpasterzy, animatorów i wszystkich, którzy pragną czytać Pismo Święte (Tarnów: Wydawnictwo Biblos 2018) 111-114.

9. „Powołanie i posłannictwo proroka Amosa (Am 7,12-17)”, Krąg Biblijny nr 36. Materiały dla duszpasterzy, animatorów i wszystkich, którzy pragną czytać Pismo Święte (Tarnów: Wydawnictwo Biblos 2018) 114-118.

\section{Sympozja:}

1. Referat: "The Aramaic Bible Project", International Meeting of Society of Biblical Literature. Organizacja panelu: "Biblical Studies in Poland in the Context of Current Tendencies", Berlin, 7-11.08.2017.

2. Referat: „Wpływ tradycji targumicznych na teksty Nowego Testamentu”, 55. Sympozjum Biblistów Polskich, Legnica, 18-20.09.2017.

3. Dwa referaty: „Jezus i pierwsi chrześcijanie w Talmudzie” oraz „Znaczenie targumów dla argumentacji fundametalnoteologicznej”, Ogólnopolskie Sympozjum Stowarzyszenia Teologów Fundamentalnych, Łomża, 21-22.09.2017.

4. Referat: „Biblia Aramejska w przekładzie na język polski jako przestrzeń dialogu pomiędzy judaizmem i chrześcijaństwem”, Międzynarodowa Konferencja: „Świat kultur a tradycja słowacko-polskiego pogranicza”, Presov, Słowacja, 16-18.10.2017.

5. Organizacja i udział: XIII Międzynarodowe Jesienne Dni Biblijne „The Dead Sea Scrolls Seventy Years Later. Manuscripts, Traditions, Interpretations, and Their Biblical Context”, Lublin - KUL, 24-26.10.2017.

6. Referat: „Cud działania Ducha Świętego w prześladowanej wspólnocie Mateuszowej”, Szkoła Biblijna - „Znaki i cuda w Ewangelii wg św. Mateusza”, Szczecin-Uniwersytet Szczeciński, 28.10.2017.

7. Referat: „Eschatologia w ujęciu Biblii Aramejskiej”, III Sympozjum im. o. Augustyna Jankowskiego: ,Eschatologia, apokalipsa, a może po prostu koniec świata?”, Opactwo Benedyktynów w Tyńcu, 6.11.2017. 
8. Udział w obchodach 100-lecia istnienia KUL, Papieska Akademia Nauk, Rzym, 25-26.04.2018.

9. Referat: „Zasady katolickiej interpretacji tekstów biblijnych: Obecność Biblii w katechezie”, Konferencja międzynarodowa: „Apostolat biblijny a wyzwania współczesności. Bibliodrama w ewangelizacji”, Ołtarzew, 24-25.05.2018.

10. Referat: „Mistrz i jego uczniowie w Starym i Nowym Testamencie”, IV Sympozjum z cyklu: „Duchowość Ziemi Świętej”, Lublin - KUL, 29.05.2018.

\section{Szkolenia:}

1. Udział w wykładach $w$ ramach seminarium translatorskiego organizowanego przez Nida Institute (USA), Rzym, 11-15.09.2017.

\section{Recenzje:}

1. Recenzja habilitacyjna ks. dra Tomasza Siemieńca na podstawie rozprawy pt. Teologiczna rola ,ludzi” ("oi anthrōpoi) w Apokalipsie Janowej (Kielce: Jedność 2018).

\section{Udział w komisjach:}

1. Członek komisji w sprawie nadania tytułu profesorskiego dr. hab. Gabrielowi Pala (Presov, Wydział Teologii Uniwersytetu w Presovie - Słowacja), 16.04.2018.

2. Recenzent komisji w sprawie nadania stopnia doktora habilitowanego dla ks. dra Tomasza Siemieńca (Wydział Teologii KUL) 18.06.2018.

3. Przewodniczący komisji ds. postępowania habilitacyjnego dr Małgorzaty Skowronek (Wydział Filologiczny Uniwersytetu Łódzkiego) 29.06.2018.

\section{Promocja pracy doktorskiej:}

1. Mateusz Targoński, Arcykapłan Pinchas i jego gorliwość o Boga. Model pobożności w judaizmie Drugiej Świątyni i Nowym Testamencie, Lublin 2018.

\section{Recenzje prac doktorskich:}

1. Ks. Tadeusz Knut, Biblijne opowiadanie o mieście i wieży Babel (Rdz 11,19) w interpretacji żydowskich pism z okresu Drugiej Światyni (Warszawa - UKSW 2017), ss. 272.

2. Grzegorz Olek, Rola anachronii w Dziejach Apostolskich i w II księdze de Bello Judaico Józefa Flawiusza (Warszawa-CHAT 2017), ss. 245. 
3. Ks. Janusz Pycia, Specyfika Łukaszowego orędzia o zmartwychwstaniu Jezusa (Tarnów - Kraków - UPJPII 2017), ss. 330.

4. Williams Peter Awoshiri, Towards a Servant Model of Leadership: A Socio-Rhetorical Investigation of the Johannine Farewell Discourse (John 1317) (Warsaw - UKSW 2018), ss. 311.

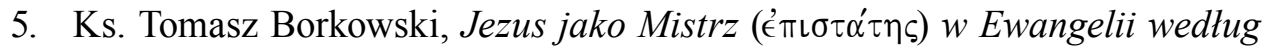
św. Łukasza (Warszawa - UKSW 2018), ss. 372.

\section{Promocje prac magisterskich:}

1. Br. Dawid Napiwodzki OFMCap, Nauka Jezusa o bezżeństwie (Mt 19,10-12) w kontekście życia monastycznego wspólnoty z Qumran, Lublin 2018.

2. Paweł Leonik SSP, Historyczny, pedagogiczny i kultyczny wymiar Arki Przymierza w narracji o sprowadzeniu Arki do Jerozolimy (2 Sm 6,1-23), Lublin 2018.

3. Dorota Chwiła FMA, Zapowiedź Jezusa o prześladowaniach Jego uczniów $w$ kontekście polemiki pomiędzy Synagoga i Kościołem. Studium historyczno-egzegetyczne, Lublin 2018.

\section{Działania popularyzujące Biblię:}

1. Zorganizowanie X Edycji Kursu Formacji Biblijnej w KUL 2017-2018 (Podstawowy Kurs Formacji Biblijnej, Pogłębiony Kurs Formacji Biblijnej, Wykłady monograficzne).

2. Prowadzenie lectio divina w Archikatedrze Lubelskiej (raz w miesiącu).

3. Prowadzenie spotkań z cyklu: „W Blasku i Mocy Pisma Świętego” w kościele NMP Niepokalanej w Lublinie (raz w miesiącu).

4. Spotkanie Biblijne, Ognisko Światła i Miłości. Wygłoszenie cyklu referatów pt. „Modlitwa Ojcze nasz”, Kaliszany, 14-15.10.2017.

5. Spotkanie Biblijne, Ognisko Światła i Miłości. Wygłoszenie cyklu referatów pt. „Magnificat Maryi”, Kaliszany 9-10.12.2017.

6. Dom Rekolekcyjny „Promień” Sióstr Służek Maryi Niepokalanej, Spotkanie Biblijne pt. „W skarbcu biblijnej mądrości”. Wygłoszenie cyklu referatów pt.: „Szaweł i jego życiowa droga z ciemności do światłości”, Nałęczów, 1921.01.2018.

7. II Narodowe Czytanie Pisma Świętego. Organizacja i wprowadzenie, Lublin - KUL 13.04.2018.

8. Niedziela Biblijna w Archidiecezji Lubelskiej. Przewodniczenie jako moderator Dzieła Biblijnego i organizacja w kościele Matki Bożej Zwycięskiej, Lublin, 15.04.2018. 
9. Dom Rekolekcyjny „Promień” Sióstr Służek Maryi Niepokalanej, Spotkanie Biblijne pt. „W skarbcu biblijnej mądrości”. Wygłoszenie cyklu referatów pt.: „Doświadczenie żywego Boga w życiu św. Pawła”, Nałęczów, 20-22.04.2018.

10. Spotkanie Biblijne, Ognisko Światła i Miłości. Wygłoszenie cyklu referatów pt. „Magnificat Maryi”, Kaliszany, 12-13.05.2018.

11. Trybunał Koronny. Ogłoszenie ks. Infułata Grzegorza Pawłowskiego Honorowym Obywatelem Miasta Lublina. Wygłoszenie laudacji, Lublin, 15.05.2018.

12. Promocja książki „Wprowadzenie do Biblii Aramejskiej” - z udziałem abp Stanisława Gądeckiego, rabina Michaela Schudricha, prof. Małgorzaty Nowak-Barcińskiej, dr Pawła Rytela-Andrianika, Lublin - KUL 16.05.2018.

13. Ogólnopolski Konkurs Wiedzy Biblijnej organizowany przez „Civitas Christiana”. Merytoryczne przygotowanie pytań finałowych i przewodniczenie komisji egzaminacyjnej, Niepokalanów, 4-5.06.2016.

14. Nadzwyczajne posiedzenie Rady Wydziału Teologii. Wręczenie Złotego Dyplomu Wydziału Teologii dla ks. abp Zbigniewa Stankiewicza, Metropolity Rygi. Wygłoszenie laudacji, Lublin - KUL, 9.06.2018.

\section{2) Ks. dr Tomasz Bąk}

\section{Artykuły naukowe i recenzje:}

1. „Gniew Jezusa pod Cezareą Filipową. Studium egzegetyczne Mk 8,31-33”, Verbum Vitae 33 (2018) 155-178.

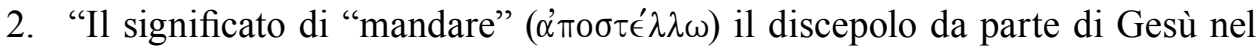

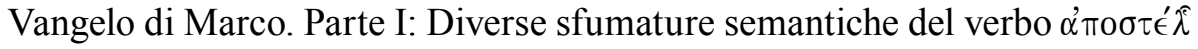
$\lambda \omega$ ", Resovia Sacra 24 (2017) 5-23.

3. "Guarigione di un cieco (Mc 8,22-26) nel contesto del Vangelo di Marco", The Biblical Annals 8/3 (2018) 319-361.

4. [Recenzja] A.M. Wajda, Szkice z biblijnego zwierzyńca (Kraków: Petrus 2016), Verbum Vitae 32 (2017) 475-485.

\section{Publikacje popularnonaukowe:}

1. „Czytaj z potrzeby serca”, Niedziela Rzeszowska 18 (2018) V.

2. Cykl kazań biblijnych na stronę internetową Dzieła Biblijnego

\section{Grant naukowy:}

1. W sierpniu 2017 r. z Narodowego Centrum Nauki przyznany grant MINIATURA 1 o następującym temacie badawczym: „Edycja krytyczna i anali- 
za filologiczna pierwszego rozdziału Deutero-Izajasza (Iz 40) na podstawie koptyjskiego manuskryptu sa 52 (M 568) w świetle innych rękopisów koptyjskich dialektu saidzkiego oraz greckiego tekstu Septuaginty". Efektem grantu jest artykuł naukowy, ukazujący się w bieżącym numerze The Biblical Annals.

\section{Kwerendy naukowe:}

1. Pontificio Istituto Biblico, Rzym, Włochy, 5-17.02.2018. Kwerenda biblioteczna związana z realizacją grantu Miniatura 1.

\section{Recenzje prac magisterskich:}

1. Dawid Napiwodzki OFMCap, Nauka Jezusa o bezżeństwie (Mt 19,10-12) w kontekście życia monastycznego wspólnoty z Qumran. Praca magisterska napisana na seminarium z Literatury Międzytestamentalnej i Nauk Pomocniczych Biblistyki pod kierunkiem ks. prof. dr. hab. Mirosława S. Wróbla (Lublin 2018).

2. Paweł Leonik SSP, Historyczny, pedagogiczny i kultyczny wymiar Arki Boga w narracji o sprowadzeniu Arki do Jerozolimy (2 Sm 6,1-23). Praca magisterska napisana na seminarium z Literatury Międzytestamentalnej i Nauk Pomocniczych Biblistyki pod kierunkiem ks. prof. dr. hab. Mirosława S. Wróbla (Lublin 2018).

3. Dorota Chwiła FMA, Zapowiedź Jezusa o prześladowaniach Jego uczniów w kontekście polemiki pomiędzy Synagoga i Kościołem. Studium historyczno-egzegetyczne $J$ 15,18-16,4a. Praca magisterska napisana na seminarium z Literatury Międzytestamentalnej i Nauk Pomocniczych Biblistyki pod kierunkiem ks. prof. dr. hab. Mirosława S. Wróbla (Lublin 2018).

\section{Działalność odczytowa i wykłady:}

1. Działalność odczytowa: „Młodość św. Pawła i jego przemiana pod Damaszkiem w świetle Dziejów Apostolskich i wybranych Listów", Instytut Teologiczno-Pastoralny w Rzeszowie, Diecezjalne Studium Biblijne, 21.10.2017.

2. Działalność odczytowa: „Sobór Jerozolimski i druga wyprawa misyjna św. Pawła Apostoła”, Instytut Teologiczno-Pastoralny w Rzeszowie, Diecezjalne Studium Biblijne, 28.10.2017.

3. Działalność odczytowa: „Trzecia wyprawa misyjna św. Pawła Apostoła”, Instytut Teologiczno-Pastoralny w Rzeszowie, Diecezjalne Studium Biblijne, 04.11.2017. 
4. Działalność odczytowa: „Z Cezarei Nadmorskiej do Rzymu. Ostatnie lata św. Pawła Apostoła”, Instytut Teologiczno-Pastoralny w Rzeszowie, Diecezjalne Studium Biblijne, 25.11.2017.

5. Wykłady: „Egzegeza Starego Testamentu: Pięcioksiąg”, Wyższe Seminarium Duchowne w Rzeszowie (rok IV, semestr I, rok akademicki 2017/2018).

6. Wykłady: „Egzegeza Nowego Testamentu: Pisma Pawłowe”, Wyższe Seminarium Duchowne w Rzeszowie (rok III, semestr II; rok akademicki 2017/2018).

7. Wykłady: „Księga Rodzaju. Wprowadzenie oraz analiza egzegetyczno-teologiczna wybranych fragmentów", Instytut Teologiczno-Pastoralny w Rzeszowie. Podyplomowe studia katechetyczne (semestr II; rok akademicki 2017/2018).

\section{Audycja radiowa:}

„Jesteśmy napełnieni Duchem Świętym. Wprowadzenie do X Tygodnia Biblijnego”, Katolickie Radio „Via”, Rzeszów, 14.04.2018.

\section{3) Ks. dr hab. Henryk Drawnel, prof. KUL}

\section{Artykuł naukowy:}

1. "Qumran and the Ancient Near East", T\&T Clark Companion to the Dead Sea Scrolls (ed. G.J. Brooke, Ch. Hempel) (London: T\&T Clark Bloomsburry 2018) 109-118.

\section{Artykuł popularnonaukowy:}

1. „Manuskrypty znad Morza Martwego”, Przeglad Uniwersytecki 6 (170) (2017) 51.

\section{Sympozja i wykłady:}

1. Organizator: $13^{\text {th }}$ International Biblical Congress "The Dead Sea Scrolls Seventy Years Later. Manuscripts, Traditions, Interpretations, and Their Biblical Context", KUL, 24-26.10.2017.

2. Prowadzenie konferencji międzynarodowej: $13^{\text {th }}$ International Biblical Congress, "The Dead Sea Scrolls Seventy Years Later. Manuscripts, Traditions, Interpretations, and Their Biblical Context", KUL, 24-26.10.2017. 
3. Referat na konferencji międzynarodowej: "Dead Sea Scrolls Seventy Years Later: An Overview of Dissenting Opinions", $13^{\text {th }}$ International Biblical Congress "The Dead Sea Scrolls Seventy Years Later. Manuscripts, Traditions, Interpretations, and Their Biblical Context”, KUL, 24-26.10.2017.

4. Referat „Enoch na krańcach świata: Linia horyzontu w astronomii Księgi Henocha (rozdz. 33-36)" na konferencji międzynarodowej: "Aramaic Science in Qumran", Budapeszt, 15-16.05.2018.

5. Prowadzenie konferencji: „Sługa Ewangelii”. Sesja dla uczczenia pamięci ks. Profesora Józefa Kudasiewicza, KUL, 18.11.2018.

6. Wykład: „Anioły i złe duchy w Etiopskiej Księdze Henocha”, Klasztor oo. Dominikanów w Lublinie, 15.04.2018.

7. Wykład: „Manuskrypty z Qumran: Pomiędzy historią a archeologią”, Klasztor oo. Dominikanów w Lublinie, 27.05.2018.

\section{4) Ks. dr hab. Dariusz Dziadosz}

\section{Artykuły naukowe:}

1. „Twoje stowo jest lampa dla moich stóp i świattem na mojej ścieżce (Ps 119,105). Teologiczna lektura idei światła w tradycjach Starego Testamentu", Ethos 30/3 (2017) 19-42.

2. „Nie wymieniaj przyjaciela za pieniądze ani brata prawdziwego na złoto z Ofiru (Syr 7,18). Pieniądz w Biblii”, Ethos 30/1 (2018) 67-86.

\section{Referat na konferencji naukowej:}

1. „Biblijna i pozabiblijna koncepcja śmierci człowieka”, wygłoszony na krajowej konferencji „O godne umieranie”, Przemyśl, 9.11.2017.

\section{Promocja pracy doktorskiej:}

1. Ks. Łukasz Florczyk, Bóg Izraela w rozumieniu nie-Izraelitów. Studium historyczno-krytyczne wybranych tradycji deuteronomistycznej historiografii (Joz-2Krl) (KUL; Lublin 2018).

\section{Promocja pracy magisterskiej:}

1. Krzysztof Senejko, Ezechiel strażikiem Izraela. Studium egzegetyczno-teologiczne tradycji Ez 3,16-21; 33,1-9 (UPJPII; Kraków 2018). 


\section{5) Ks. dr Marcin Kowalski}

\section{Monografie:}

1. 2 List do Koryntian (Biblia Impulsy. Nowy Testament 7; Katowice: Księgarnia św. Jacka 2018) ss. 135.

2. Szustak OP - M. Kowalski, Straszna książka (Kraków: Stacja7.pl 2018) ss. 519.

\section{Artykuły naukowe, hasła słownikowe i recenzje:}

1. „Retoryka i socjoretoryka w lekturze tekstów Nowego Testamentu Cz. 2: Socjo-retoryka - projekt holistycznej lektury tekstu", The Biblical Annals 7/1 (2017) 107-147.

2. „«Spodobało się Bogu objawić Syna swojego we mnie» (Ga 1,15-16). Pochodzenie i natchniony charakter Ewangelii Pawła", Natchnienie Pisma Świętego. W świetle świadectw tekstów o nich samych (red. M. Wróbel - S. Szymik - K. Napora) (Analecta Biblica Lublinensia 15; Lublin: Wydawnictwo KUL 2017) $151-172$.

3. „Nowe życie jak ziarno gorczycy. Spójność argumentacji retorycznej Pawła w Rz 5 - 8", The Biblical Annals 7/4 (2017) 459-485.

4. "God the Benefactor and His Human Clients in Rom. 5-8", The Biblical Annals 8/1 (2018) 47-69.

5. „Stoicka pneuma a Pawłowa koncepcja Ducha w Rz 8. Cz.1. Argumentacja Rz 8 i przegląd badań nad stoicką pneuma u Pawła", The Biblical Annals $8 / 3$ (2018) 421-456.

6. „Stoicka pneuma a Pawłowa koncepcja Ducha w Rz 8. Cz.2. Paweł i stoicy na temat Ducha - podobieństwa i różnice", The Biblical Annals 8/4 (2018) 491-543.

7. "The Brokerage of the Spirit in Romans 8", Catholic Biblical Quarterly 80/4 (2018) 636-654.

8. „Wolność”, Nowy Słownik Teologii Biblijnej (red. H. Witczyk) (Kielce: Jedność 2017) 959-961.

9. „Znak”, Nowy Stownik Teologii Biblijnej (red. H. Witczyk) (Kielce: Jedność 2017) 1004-1005.

10. [Recenzja] Akiva Cohen, Matthew and the Mishnah. Redefining Identity and Ethos in the Shadow of the Second Temple's Destruction (Wissenschaftliche Untersuchungen zum Neuen Testament, 2. reihe 418; Tübingen, Mohr Siebeck, 2016), Biblica 98/2 (2017) 310-314.

11. [Recenzja] Jeffrey W. Aernie, Is Paul also among the Prophets? An Examination of the Relationship between Paul and the Old Testament Prophet- 
ic Tradition in 2 Corinthians (LNTS 467; London - New York: T\&T Clark 2012), The Biblical Annals 7/3 (2017) 375-379.

12. [Recenzja] Lutz Doering, Ancient Jewish Letters and the Beginnings of Christian Epistolography (WUNT I/298; Tübingen: Mohr Siebeck 2012), The Biblical Annals 7/4 (2017) 551-555.

13. [Recenzja] Mark T. Finney, Honour and Conflict in the Ancient World. 1 Corinthians in Its Greco-Roman Social Setting (LNTS 460; London - New York: T \& T Clark 2012), The Biblical Annals 7/4 (2017) 557-561.

14. [Recenzja] Stanley E. Porter - Christopher D. Land, Paul and His Social Relations (Pauline Studies 7; Leiden - Boston: Brill 2013), The Biblical Annals 8/4 (2018) 639-644.

\section{Publikacje popularnonaukowe:}

1. Cykl kazań biblijnych na stronę internetową Dzieła Biblijnego.

2. Homilie publikowane w periodyku Współczesna Ambona.

\section{Sympozja, seminaria i referaty:}

1. Organizacja wspólnie z Pontificia Università Urbaniana oraz Nida Institute i udział w seminarium translatorskim poświęconym VI wydaniu Biblii Tysiąclecia, Rzym, 11-15.09. 2017.

2. Udział w XIV Walnym Zebraniu i 55 Sympozjum Biblistów Polskich, Wyższe Seminarium Duchowne, Legnica, 18-20.09.2017.

3. Udział w XIII Międzynarodowych Jesiennych Dniach Biblijnych: „The Dead Sea Scrolls Seventy Years Later. Manuscripts, Traditions, Interpretations, and Their Biblical Context”, KUL, Lublin, 25-26.10.2017.

4. Referat: „O Duchu, który w nas mieszka (Rz 8,9). Co ma wspólnego św. Paweł ze starożytną filozofią i medycyną?”, Wiosenne Dni Biblijne 2018 , «Weźmijcie Ducha Świętego» (J 20,22). Duch Święty w Kościele”, KUL, Lublin, 20.03.2018.

5. Udział w XV Walnym Zebraniu i 56 Sympozjum Biblistów Polskich, Wyższe Seminarium Duchowne, Łomża, 17-19.09.2018.

6. Referat: „Stoicka pneuma a Pawłowa koncepcja Ducha w Rz 8”, 56. Sympozjum Biblistów Polskich, Łomża, 17-19.09.2018.

7. Organizacja wspólnie z Pontificia Università Urbaniana oraz Nida Institute i udział w seminarium translatorskim poświęconym VI wydaniu Biblii Tysiąclecia, Rzym, 24-28.09.2018.

8. Organizacja XIV Międzynarodowych Jesiennych Dni Biblijnych „Rosa Twoja jest rosą światłości, a ziemia wyda cienie zmarłych (Iz 26:19). Zmar- 
twychwstanie w Biblii i kulturze starożytnej basenu Morza Śródziemnego", KUL, Lublin, 23-24.10.2018.

\section{Kierowanie i realizacja projektów krajowych i zagranicznych:}

Pismem Konferencji Episkopatu Polski z dnia 10 czerwca 2016 r. ks. Marcin Kowalski został powołany do nowej Redakcji Naukowej Biblii Tysiąclecia. Jest ona odpowiedzialna za przygotowanie szóstego wydania tej ważnej dla Kościoła w Polsce Biblii. Wraz z o. prof. Andrzejem Gieniuszem CR odpowiada za zespół redakcyjny Nowego Testamentu. W związku z tym wraz z Papieskim Uniwersytetem Urbaniana oraz amerykańskim Nida Institute, będącym częścią American Bible Society, ks. Kowalski jest odpowiedzialny za organizację seminariów translatorskich w Rzymie. Mają one na potrzeby szóstego wydania Biblii Tysiąclecia przygotować zespół tłumaczy i wprowadzić go w kwestie związane z teorią i praktyką translatoryki biblijnej. Do tej pory odbyły się trzy seminaria (wrzesień 2017, luty 2018, wrzesień 2018). Inicjatywa ma za zadanie zarówno integrację środowiska polskiego, jak i otwieranie go na współpracę z uznanymi zagranicznymi ośrodkami badawczymi.

\section{Działalność dydaktyczna:}

1. Cyk1 wykładów: „New Testament and Family Life. Part.1”, „New Testament and Family Life”. Part.2; „Introduction to Isaiah”, Elizabeth Ann Seton Parish Shrub Oak, NY, USA, sierpień - wrzesień 2017 r.

2. Wykłady dla katechetów w ramach Studium podyplomowego KUL: „Pięcioksiąg i księgi historyczne", WSD Kielce, luty - czerwiec 2018 r.

3. Wykłady dla katechetów w ramach Studium podyplomowego KUL: „Listy św. Pawła" (15h), KUL, Lublin, luty - czerwiec $2018 \mathrm{r}$.

4. Cykl wykładów: The Creation and Fall. Lessons from Gen 1-3: 1) "Gen 1: The World as God's Temple according to the Priest"; 2) "Gen 2-3: The Garden, the Presence of Evil and the First Gospel"; 3) "Gen 1-3 in Ancient and Contemporary Culture (Myth, Literature and Evolution)", Elizabeth Ann Seton Parish Shrub Oak, NY, USA, sierpień 2018 r.

\section{Promotor prac magisterskich:}

1. Dk. Konrad Wójcik, Znaczenie motywu wędrówki Izraela przez pustynię w 1 Kor 10,1-13. Studium egzegetyczno-teologiczne (KUL, 10.05.2018).

2. S. Maria Emilia Kąkol, Wiara w Chrystusa jedyna droga usprawiedliwienia grzesznej ludzkości. Analiza egzegetyczno - teologiczna Rz 3,21-31 (KUL, 28.06.2018). 


\section{Promotor pomocniczy pracy doktorskiej:}

1. Ks. Nikos Skuras, Objawienie Piotrowi misji ad gentes (Dz 10-1-48). Studium egzegetyczno-teologiczne (KUL 2018).

\section{Kwerendy naukowe:}

1. Pontificio Istituto Biblico, Rzym, Włochy, 11-16.09.2017.

2. Pontificio Istituto Biblico, Rzym, Włochy, 24-29.09.2018.

\section{Audycje radiowe i telewizyjne:}

1. Telewizyjny Uniwersytet Biblijny (TV Trwam).

2. „Wędrówka Izraela przez pustynię. Szemranie (Lb 11,1-3)”, 28.10.2017.

3. „Wody Meriba i grzech Mojżesza (Lb 20,1-13)”, 13.01.2018.

4. „Wywyższenie węża na pustyni (Lb 21,4-9)”, 10.03.2018.

5. „Początek cyklu Balaama (Lb 22,2-40)”, 09.06.2018.

6. Seria programów TV „Słowo Życia” (TV Trwam).

7. Programy radiowe „Rozmowy niedokończone” i „Szukając Słowa Bożego” (Radio Maryja).

\section{6) Ks. dr Adam Kubiś}

1. W roku akademickim 2017-2018 ks. dr A. Kubiś był zatrudniony w INB KUL na etacie naukowym.

\section{Artykuły naukowe, recenzje:}

1. „Dlaczego w narracji Janowej Piotr nie płakał po zaparciu się Jezusa? Kilka refleksji na temat prezentacji postaci Piotra w J 18,1-27", Resovia Sacra 24 (2017) 233-262. Przedruk w Lumen Bibliae. Pismo nowej ewangelizacji przy ogrodzie biblijnym w Myczkowcach 6 (2016) 73-98.

2. „Jerozolimskie elżbietanki i bibliści polscy - historia spotkania”, Zeszyty Naukowe Stowarzyszenia Biblistów Polskich 14 (2017) 495-500.

3. „Kobieta cierpiąca na krwotok oraz córka Jaira jako symbol Izraela. Próba analizy symbolicznej Mk 5,21-43”, Studia nad Ewangelia wedtug św. Marka. Nowy Testament: geneza - interpretacja - aktualizacja (red. W. Linke J. Kręcidło) (Lingua Sacra. Monografie 8; Warszawa: Bractwo Słowa Bożego - Ząbki: Apostolicum 2017) 66-111.

4. „The Rhetorical Syncrisis in the Johannine Presentation of Jesus and Peter", The Biblical Annals 7/4 (2017) 487-529. 
5. „Dlaczego w relacji Mateusza Jezus wjeżdżał do Jerozolimy na dwóch

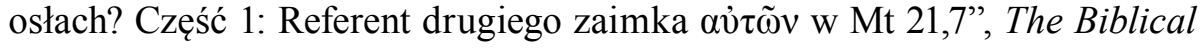
Annals 8/1 (2018) 29-45.

6. „Dlaczego w relacji Mateusza Jezus wjeżdżał do Jerozolimy na dwóch osłach? Część 2: Motywy umieszczenia dwojga zwierząt w tekście Mateusza", The Biblical Annals 8/2 (2018) 213-258.

7. [Recenzja] William Randolph Bynum, The Fourth Gospel and the Scriptures. Illuminating the Form and Meaning of Scriptural Citation in John 19:37 (Supplements to Novum Testamentum 144; Leiden - Boston, MA: Brill 2012), The Biblical Annals 7/3 (2017) 381-387.

8. [Recenzja] Massimo Grilli, Il Vangelo secondo Giovanni. Elementi di introduzione e teologia (Biblica; Bologna: Edizioni Dehoniane Bologna 2016), The Biblical Annals 7/3 (2017) 389-392.

9. [Recenzja] J. Daniel Hays, The Temple and the Tabernacle. A Study of God's Dwelling Places from Genesis to Revelation (Grand Rapids, MI: Baker Books 2016), The Biblical Annals 8/2 (2018) 283-287.

\section{Sympozja i wykłady:}

1. Współorganizator: „International Seminar on the Biblia Hebraica Quinta”, Lublin-KUL, 24-26.10.2017.

2. Współorganizator: $13^{\text {th }}$ International Biblical Congress "The Dead Sea Scrolls Seventy Years Later. Manuscripts, Traditions, Interpretations, and Their Biblical Context", KUL, 24-26.10.2017.

3. Referat: „Użycie retorycznego synkrisis w Ewangelii Janowej”, w ramach sympozjum „Ewangelia według świętego Jana. Geneza - interpretacja - aktualizacja", Instytut Nauk Biblijnych UKSW, 16.11.2017.

4. Prowadzenie sesji: Wiosenne Sympozjum Biblijne „Weźmijcie Ducha Świętego" (J 20,22). Duch Święty w Kościele”, KUL, 20.03.2018.

5. Prowadzenie sesji biblijnej (16 kwietnia): 50. Jubileuszowy Tydzień Eklezjologiczny, KUL, 16-20.04.2018.

6. Wykład: „Baranek Boży w IV Ewangelii - znaczenie metafory”, Studium Biblijne Diecezji Rzeszowskiej, 9.12.2017.

7. Wykład: „Metafora oblubieńcza w Nowym Testamencie”, X Niedziela Biblijna. Katedra rzeszowska, Rzeszów, 15.04.2018.

8. Wykład: „Czwarty kielich. Ku lepszemu zrozumieniu Ostatniej Wieczerzy”, Konferencja biblijna „Ku lepszemu zrozumieniu Pisma Świętego”, organizowana przez Katedrę Teologii Małżeństwa i Rodziny Uniwersytetu Papieskiego Jana Pawła II w Krakowie, Instytut Teologii Fundamentalnej KUL, Instytut Teologiczno-Pastoralny w Rzeszowie, Katedrę Roślin Ozdobnych Uniwersytetu Rolniczego w Krakowie, Ośrodek Caritas w Myczkowcach, 12.05.2018. 
9. Wykład: „Nowy Testament a archeologia. Hipotezy wiarygodne i niewiarygodne”, Studium Biblijne Diecezji Rzeszowskiej, 19.05.2018.

10. Wykład: „Jan Chrzciciel - jego miejsce w nowotestamentowej typologii oblubieńczej”, Studium Biblijne Diecezji Rzeszowskiej, 19.05.2018.

11. Wykład: „Prehistoria biblijna (Rdz 1-11) we współczesnej biblistyce”, Formacja stała prezbiterów diecezji rzeszowskiej, Dom Diecezjalny „Tabor”, Rzeszów 21.05.2018.

\section{Kwerendy naukowe:}

1. École biblique et archéologique française de Jérusalem, Jerozolima, Izrael, 31.07 - 11.09.2017.

2. Pontificio Istituto Biblico, Rzym, Włochy, 29.09. - 21.10.2017

3. École biblique et archéologique française de Jérusalem, Jerozolima, Izrael, 12-17.02.2018.

4. École biblique et archéologique française de Jérusalem, Jerozolima, Izrael, 4-7.04.2018.

\section{Promocje prac magisterskich:}

1. Robert Żarnowski, Tożsamość dwóch świadków Chrystusa. Studium literacko-teologiczne Ap 11,3-13 (UPJP2 2018).

2. Jakub Lorenc, Motyw jedności w Modlitwie Arcykapłańskiej Jezusa (J 17,1-26). Studium egzegetyczno-teologiczne (WSD Rzeszów - UPJP2 2018).

\section{Audycje radiowe i telewizyjne:}

1. „Świętość w Biblii”, Katolickie Radio „Via” Rzeszów, 1.11.2017.

2. „Rola kobiet w starotestamentalnej historii zbawienia”, w serii „Pisma i znaki”, Polskie Radio Rzeszów, 8.11.2017.

3. „Rola kobiet w nowotestamentalnej historii zbawienia”, w serii „Pisma i znaki”, Polskie Radio Rzeszów, 15.11.2017.

4. „Narodziny Bożego Narodzenia”, Katolickie Radio „Via”, Rzeszów, 25.12.2017.

5. „Epifania - geneza i znaczenie święta”, Polskie Radio Rzeszów, 3.01.2018.

6. „Judasz”, Katolickie Radio „Via”, Rzeszów, 30.03.2018.

7. „Świadkowie zmartwychwstania: Maria Magdalena”, Katolickie Radio „Via”, Rzeszów, 1.04.2018.

8. „Świadkowie zmartwychwstania: Uczniowie z Emaus”, Katolickie Radio „Via”, Rzeszów, 2.04.2018. 


\section{Praca dydaktyczna:}

1. Visiting professor Papieskiego Uniwersytetu Urbaniańskiego w Rzymie, 2-19 października 2017 r. Wykład „Between Sinfulness and Sinlessness. The Concept of Sin in the Corpus Johanneum" w wymiarze 24 godzin wykładowych.

2. Wykład: „Ewangelie synoptyczne”, 45 godzin, WSD Rzeszów.

3. Wykład: „Literatura mądrościowa Starego Testamentu”, 45 godzin, WSD Rzeszów.

4. Wykład: „Archeologia i geografia biblijna”, 30 godzin, WSD Rzeszów.

\section{7) P. dr hab. Krzysztof Mielcarek, prof. KUL}

\section{Artykuły naukowe, recenzje:}

1. „Pieśń na trzy Głosy. Natchnione świadectwo synoptyków” (Natchnienie Pisma świętego. W świetle świadectwa tekstów o nich samych (red. S. Szymik) (ABL 15; Lublin: Wydawnictwo KUL 2017) 99-109.

2. „Zachariasz - kapłan, ojciec, ofiarnik”, The Biblical Annals 7/2 (2017) 359-373.

3. „«Plemię żmijowe» (Łk 3,7) i pokrewne wypowiedzi w Łk-Dz. Diagnoza sytuacji współczesnych Jezusowi czy kondycji człowieka?", The Biblical Annals 8/2 (2018) 191-211.

4. „Z doświadczenia dialogów na forum światowym”, Lublin - miasto zgody religijnej. Ekumenizm $w$ historii, teologii, kulturze (red. S. Pawłowski, S.J. Żurek) (Źródła i monografie 458; Lublin: TN KUL 2017) 239-244.

5. „,Lukasz Ewangelista”, Nowy Stownik Teologii Biblijnej (red. H. Witczyk) (Lublin - Kielce: Towarzystwo Naukowe KUL - Jedność, 2017) 470.

6. „Opętanie”, NSTB, 653-654.

7. „Przekleństwo”, NSTB, 746-747.

8. „Świątynia”, NSTB, 871-874.

9. „Teofania”, NSTB, 890-892.

10. „Ubóstwo”, NSTB, 909-911.

11. „Wierność”, NSTB, 941-942.

12. „Wspólnota”, NSTB, 961-962.

13. [Recenzja] Geir Otto Holmås, Prayer and Vindication in Luke-Acts. The Theme of Prayer within the Context of the Legitimating and Edifying Objective of the Lukan Narrative (Library of New Testament Studies 433; New York - London: T\&T Clark, 2011), The Biblical Annals 7/1 (2017) 157-162. 


\section{Artykuły popularnonaukowe:}

1. „Teologia. Stary Testament. Cz. II/6. Czas sług słowa: profetyzm izraelski do wygnania ( $2 \mathrm{Krl}, \mathrm{Am}, \mathrm{Oz}$, Iz, Mi)", Krag Biblijny nr 34. Materiaty dla duszpasterzy, animatorów $i$ wszystkich, którzy pragna czytać Pismo Święte (Tarnów: Wydawnictwo Biblos 2017) 111-118.

2. „Teologia. Stary Testament. Cz. II/7. Czas sług słowa: profetyzm izraelski na wygnaniu (Ez, DIz), Krag Biblijny nr 35. Materiaty dla duszpasterzy, animatorów i wszystkich, którzy pragna czytać Pismo Święte (Tarnów: Wydawnictwo Biblos 2017) 117-124.

3. „Teologia. Stary Testament. Cz. II/8. Czas sług słowa: profetyzm izraelski czasu powrotu (Ag, Za, Ml)", Krag Biblijny nr 36. Materiaty dla duszpasterzy, animatorów i wszystkich, którzy pragna czytać Pismo Święte (Tarnów: Wydawnictwo Biblos 2018) 105-110.

\section{Sympozja:}

1. Udział w Sympozjum Stowarzyszenia Biblistów Polskich. Legnica, 1820.09.2017.

2. Udział w XIII Międzynarodowych Jesiennych Dniach Biblijnych: „The Dead Sea Scrolls Seventy Years Later. Manuscripts, Traditions, Interpretations, and Their Biblical Context", Lublin - KUL, 24-26.10.2017.

3. Udział w Wiosennym Sympozjum Biblijnym 2018 „«Weźmijcie Ducha Świętego» (J 20,22). Duch Święty w Kościele”, Lublin - KUL, 20.03.2018.

4. Wystąpienie na otwarciu oraz prowadzenie sesji na temat miejsca katolickiego uniwersytetu i teologii $\mathrm{w}$ relacji do innych nauk na 50. Jubileuszowym Tygodniu Eklezjologicznym: „Po co teologia?”, Lublin, 16-20.04.2018.

5. Referat: „The Experience Of Dialogue On The World Forum”, Międzynarodowy Kongres Ekumeniczny „Lublin miasto zgody religijnej”, Lublin, 2931.10.2017.

6. Wykład: „Słowo mocy i łaski w dziele św. Łukasza”, „Sługa Ewangelii”. Sesja dla uczczenia pamięci Ks. Profesora Józefa Kudasiewicza (1926-2012) w piątą rocznicę śmierci, Lublin - KUL, 18.11.2017.

7. Referat: „The Ministry of Oversight (Episkope) in the Catholic Church”, International Conference on World Mission and Evangelism, Arusha, Tanzania: "Moving in the Spirit: Called to Transforming Discipleship", 8-13.03.2018.

8. Referat: „Pentecostals in the Ecumenical Dialogues on Ecclesiology”, Faith and Order Conference: Fuller Theological Seminary, Pasadena, Kalifornia, USA, 28-30.06.2018. 


\section{Promocje prac magisterskich:}

1. Dominik Sala OP, Modlitwa Jezusa na Górze Oliwnej (Łk 22,39-46). Studium egzegetyczno-teologiczne (Kraków - UP JPII).

2. S. Zuzanna Głasek, Słowo Jezusa w służbie królestwa Bożego (Łk 4,31-44). Studium egzegetyczno-teologiczne (Lublin - KUL).

\section{Szkolenia:}

1. Udział w wykładach $w$ ramach seminarium translatorskiego organizowanego przez Nida Institute (USA), Rzym, 11-16.09.2017.

\section{Kwerendy naukowe:}

1. Fuller Theological Seminary, Pasadena, Kalifornia, USA : 25.06 - 1.07.2018.

2. École biblique et archéologique française de Jérusalem, Jerozolima, Izrael: 3-10.09.2018.

\section{Praca dydaktyczna poza KUL:}

1. Kolegium Filozoficzno-Teologiczne Polskiej Prowincji Dominikanów w Krakowie:

2. Wykład: „Ewangelie synoptyczne”, 48 godzin.

3. Wykład: „Pięcioksiąg”, 24 godziny.

4. Wykład: „Historia zbawienia”, 24 godziny.

5. Dominikańskie Studium Filozofii i Teologii w Krakowie:

6. Wykład: „Wstęp do Pisma Świętego”, 12 godzin.

7. Wykład: „Ewangelia Mateusza”, 12 godzin.

8. Studium Dominicanum w Warszawie:

9. Wykład: „Wstęp do Pisma Świętego”, 12 godzin.

10. Wykład: „Jeruzalem w dziele Łukaszowym”, 4 godziny.

11. Dominikańska Szkoła Teologii w Katowicach:

12. Wykład: „Ewangelie synoptyczne”, 12 godzin.

\section{8) Ks. dr Krzysztof Napora}

\section{Artykuł naukowy:}

1. „«Bojaźń i lęk» (Rdz 9,2), czyli o zwierzętach, które wyszły z arki... Znaczenie regulacji dotyczących relacji między człowiekiem i zwierzętami w Rdz 9,1-7”, Verbum Vitae 32(2017) 71-92. 


\section{Artykuły popularnonaukowe:}

1. „Czyj jest ten obraz...?”, Czas Serca 27/5 (2017) 38-39.

2. O faryzeuszach i uczonych w Piśmie?”, Czas Serca 27/6 (2017) 38-39.

3. „Chciał go oczyścić!”, Czas Serca 28/1 (2018) 38-39.

4. „Tak bowiem Bóg umiłował świat...”, Czas Serca 28/2 (2018) 38-39.

5. „Przyjaciel Boga-człowieka”, Czas Serca 28/3 (2018) 38-39.

6. „A mówił to wystawiając go na próbę...”, Czas Serca 28/4 (2018) 38-39.

7. „Szukam Serca Boga”, Czas Serca 28/5 (2018) 38-39.

\section{Sympozja:}

1. Udział w międzynarodowym spotkaniu SBL w Helsinkach.

2. Udział w dwóch sesjach roboczych Europejskiej Teologicznej Komisji Sercańskiej w Brukseli i w Rzymie.

\section{Audycje radiowe i telewizyjne:}

1. Seria programów TV „Słowo Życia” (TV Trwam) - 4 odcinki.

2. Programy radiowe „Rozmowy niedokończone” i „Szukając Słowa Bożego” (Radio Maryja) - 4 odcinki.

\section{Działalność dydaktyczna:}

1. Sesja biblijna dla Szkoły biblijnej z Archidiecezji Gdańskiej - 7 godzin wykładowych na temat Ojcowie nasi nam opowiedzieli, czerwiec $2018 \mathrm{r}$.

2. Regularne spotkania biblijne lectio divina (co dwa tygodnie) w parafii Dobrego Pasterza w Lublinie.

3. Cykl wykładów biblijno-pastoralnych na temat Abrahama dla Sióstr Franciszkanek Misjonarek Maryi w Łabuniach, 15-23.08.2018.

4. Wykłady dla Szkoły Biblijnej Diecezji Zamojskiej w Biłgoraju w czerwcu 2018 r.

\section{Kwerenda naukowa:}

1. Kwerenda biblioteczna w Jerozolimie w $2017 \mathrm{r}$.

\section{9) Ks. dr hab. Andrzej Piwowar}

Artykuły naukowe, recenzje, hasła słownikowe:

1. „Gniew człowieka w Księdze Mądrości Syracha”, Verbum Vitae 33 (2018) 93-127. 
2. „Funkcja składniowa przyimka $\delta ı \alpha$ z dopełniaczem po formach strony biernej w języku greckim oraz jej znaczenie teologiczne”, „Podnieście głos i śpiewajcie..." (Syr 39,14). Księga pamiątkowa dedykowana ks. dr. hab. Bogdanowi Matysiakowi, prof. UWM, w 35 lecie święceń kapłańskich i 65 lecie urodzin (red. M. Karczewski - S. Mikołajczak - J. Ruciński) (Olsztyn 2017) 159-174.

3. [Recenzja] Libri sapienziali, M. Priotto (ed.) (Parole di vita 8; Padova, Messaggero di Sant'Antonio 2015), The Biblical Annals 8/1 (2018) 141-151.

4. [Recenzja] M.J. Harris, Prepositions and Theology in the Greek New Testament. An Essential Reference Resource for Exegesis (Grand Rapids, MI: Zordevan 2012), The Biblical Annals 8/2 (2018) 259-264.

5. [Recenzja] D.L. Mathewson - E.B. Emig, Intermediate Greek Grammar. Syntax for Students of the New Testament (Grand Rapids, Michigan, Baker Academic: 2016), The Biblical Annals 8/1 (2018) 129-136.

6. [Recenzja] A.J. Köstenberger - B.L. Merkle - R.L. Plummer, Going Deeper with New Testament Greek. An Intermediate Study of the Grammar and Syntax of the New Testament (Nashville, Tennessee: B\&H Academic 2016), The Biblical Annals 8/2 (2018) 269-276.

7. „Miłosierdzie Boże, II. W Nowym Testamencie”, Nowy Słownik Teologii Biblijnej (red. H. Witczyk) (Lublin - Kielce: TN KUL - Jedność, 2017) 570-573.

8. „Nahuma Księga”, NSTB, 599-600.

9. „Wiara w Biblii”, NSTB, 929-938.

10. „Władza”, NSTB, 947-950.

11. „Zapłata”, NSTB, 985-989.

\section{Artykuły popularnonaukowe:}

1. 8 ndz. zwykła C: Syr 27,4-7”, Biblia w liturgii Mszy Świętej. Tom 5: 8-14 tydzień zwykły (red. A. Paciorek - F. Mickiewicz) (Częstochowa: Święty Paweł 2018) 25-26.

2. „8 tydz. zwykły poniedziałek (I): Syr 17,24-29”, Biblia w liturgii Mszy Świętej. Tom 5: 8-14 tydzień zwykty (red. A. Paciorek - F. Mickiewicz) (Częstochowa: Święty Paweł 2018) 33-35.

3. „8 tydz. zwykły wtorek (I): Syr 35,1-12”, Biblia w liturgii Mszy Świętej. Tom 5: 8-14 tydzień zwykty (red. A. Paciorek - F. Mickiewicz) (Częstochowa: Święty Paweł 2018) 39-41.

4. „8 tydz. zwykły środa (I): Syr 36,1.4-5a.10-17”, Biblia w liturgii Mszy Świętej. Tom 5: 8-14 tydzień zwykty (red. A. Paciorek - F. Mickiewicz) (Częstochowa: Święty Paweł 2018) 45-47.

5. „8 tydz. zwykły czwartek (I): Syr 42,15-25”, Biblia w liturgii Mszy Świętej. Tom 5: 8-14 tydzień zwykty (red. A. Paciorek - F. Mickiewicz) (Częstochowa: Święty Paweł 2018) 52-54. 
6. „8 tydz. zwykły piątek (I): Syr 44,1.9-13”, Biblia w liturgii Mszy Świętej. Tom 5: 8-14 tydzień zwykty (red. A. Paciorek - F. Mickiewicz) (Częstochowa: Święty Paweł 2018) 58-59.

7. „8 tydz. zwykły sobota (I): Syr 51,12-20b”, Biblia w liturgii Mszy Świętej. Tom 5: 8-14 tydzień zwykty (red. A. Paciorek - F. Mickiewicz) (Częstochowa: Święty Paweł 2018) 64-66.

8. „11 tydz. zwykły czwartek (II): Syr 48,1-14”, Biblia w liturgii Mszy Świętej. Tom 5: 8-14 tydzień zwykty (red. A. Paciorek - F. Mickiewicz) (Częstochowa: Święty Paweł 2018) 242-244.

\section{Sympozja:}

1. Współorganizator: The $13^{\text {th }}$ International Autumn Biblical Conference: "The Dead Sea Scrolls Seventy Years Later. Manuscripts, Traditions, Interpretations, and Their Biblical Context", Lublin, 24-26.10.2017.

2. Uczestnik: Wiosenne Dni Biblijne 2018 „«Weźmijcie Ducha Świętego» (J 20,22). Duch Święty w Kościele”, Lublin, 20.03.2018.

3. Referat: „Abraham w Pochwale Ojców (Syr 44,19-21)”, „Księga Rodzaju 12 - 50 - orędzie, interpretacja i recepcja", Warszawa (UKSW), 15.05.2018.

\section{Udział w komisjach:}

1. Członek komisji ds. postępowania habilitacyjnego ks. dr. Tomasza Siemieńca (Wydział Teologii KUL, 2018).

\section{0) Ks. prof. dr hab. Stefan Szymik MSF}

\section{Książki pod redakcją:}

1. Redakcja książki: Natchnienie Pisma Świętego. W świetle świadectwa tekstów o nich samych (Lublin: Wydawnictwo KUL 2017).

\section{Artykuły naukowe, hasła słownikowe, recenzje:}

1. „Wprowadzenie”, Natchnienie Pisma Świętego w świetle świadectwa tekstów o nich samych (red. M. Wróbel - S. Szymik - K. Napora) (ABL 15; Lublin: Wydawnictwo KUL 2017) 5-10. 
2. „Współczesne modele egzegezy biblijnej w praktyce liturgicznej”, Liturgia uprzywilejowanym miejscem celebrowania słowa Bożego (red. W. Pałęcki - A. Megger) (Studia Liturgiczne 13; Lublin: TN KUL 2017) 23-39.

3. „Czyńcie sobie ziemię poddaną» $(\mathrm{Rdz} 1,28)$. Cywilizacyjny postęp ludzkości w świetle Rdz 1-11", Verbum Vitae 31 (2017) 21-44.

4. „Jezus Chrystus”, Nowy Stownik Teologii Biblijnej (red. H. Witczyk) (Lublin - Kielce: TN KUL - Jedność, 2017) 317-319, 321-322, 350-351, 352, 353-354, 359-360.

5. „Kazanie na górze”, NSTB, 418-422.

6. „Królestwo Boże”, NSTB, 442-443.

7. „Logia Jezusa”, NSTB, 463-464.

8. „Macierzyństwo”, NSTB, 485-488.

9. „Magdalena, Maria Magdalena”, NSTB, 488-490.

10. „Małżeństwo”, NSTB, 496-504.

11. „Męczeństwo”, NSTB, 555-557.

12. „Męka Pańska”, NSTB, 557-560.

13. „Natchnienie Pisma Świętego”, NSTB, 605-613.

14. „Ostatnia Wieczerza”, NSTB, 654-656.

15. „Redaktionsgeschichte”, NSTB, 771-773.

16. „Stary Testament”, NSTB, 833-835.

17. „Traditionsgeschichte”, NSTB, 899-901.

18. „Typ i typologia”, NSTB, 906-907.

19. „Zwiastowanie”, NSTB, 1007-1008.

20. [Recenzja] Tomasz Twardziłowski, Ekologiczna hermeneutyka Biblii: cele, rezultaty, zastosowania (Warszawa: Wydawnictwo UKSW 2015), Verbum Vitae 31 (2017) 365-370.

\section{Recenzja:}

1. Recenzja habilitacyjna s. dr Joanny Nowińskiej na podstawie rozprawy $C o$ styszysz poza słowem? 'Sound design' Apokalipsy św. Jana (Warszawa: Vocatio 2016).

\section{Sympozja i wykłady:}

1. Referat: „«Kto wierzy, ma życie wieczne» (J 6,47). Wiara w Jezusa Chrystusa warunkiem zbawienia i życia wiecznego”, „Jest nadzieja, bo jest życie wieczne", Górka Klasztorna k. Nakła, 18.11.2017.

2. Referat: „Idea stworzenia oryginalną myślą chrześcijańskiej (europejskiej) cywilizacji”, Wyższe Seminarium Duchowne, Bydgoszcz, 27.11.2017. 
3. Homilia i wykład na zakończenie Tygodnia Biblijnego: „Duch Święty w procesie interpretacji Pisma Świętego", Przeworsk (diec. przemyska) 21.04.2018.

\section{Praca dydaktyczna:}

1. Wykład: „Ewangelie synoptyczne”, KUL Lublin (Podyplomowe Studium Katechetyczne).

2. Wykład: „Nowy Testament: pisma Janowe”, WSD MSF Kazimierz Biskupi.

3. Wykład: „Metody badań biblijnych”, Kurs Formacji Biblijnej Archidiecezji Lubelskiej.

\section{Promocja pracy magisterskiej:}

1. Hushcha Kanstantsin MIC, Obraz Boga w Księdze Rut (obrona: 7.06.2018).

\section{1) Ks. prof. dr hab. Henryk Witczyk}

\section{Artykuły naukowe, hasła słownikowe:}

1. „Wielowymiarowa re-kreacja postaci literackich”, Biblica et Patristica Thoruniensia 11 (2018) 177-195.

2. „Wiarygodność historyczna Ewangelii - nowe kierunki badań”, Historia - Wiara - Nauka. Źródła poznania Jezusa Chrystusa (red. P. Artemiuk) (Płock: Stowarzyszenie Teologów Fundamentalnych w Polsce - Płocki Instytut Wydawniczy 2018) 70-116.

3. „Wieczerza Pańska - „pamiątka” Chrystusowej męki, śmierci i zmartwychwstania jako ekspiacyjnej Ofiary ,za wielu” i Ofiary Nowego Przymierza (1 Kor 11,23-27; Łk 22,19-20)", The Biblical Annals 8 (2018) 545-565.

4. „Gniew Boga jak gniew człowieka?”, Verbum Vitae 33 (2018) 7-18.

5. „Tajemnica Jezusa - Mesjasza i Syna Bożego, który stał się człowiekiem (J 1,1-14)", Colloquia Theologica Ottoniana 1 (2018) 59-106.

6. „Zwierzęta w historii zbawienia - co symbolizują?”, Verbum Vitae 32 (2017) 4-10.

7. „Miłosierdzie Pana - miłosierdzie wierzących”, Miłosierdzie a sprawiedliwość (Szczecin: Wydawnictwo Naukowe Uniwersytetu Szczecińskiego 2018) 43-55.

8. „Świat powierzony człowiekowi - i co dalej?”, Verbum Vitae 31 (2017) 7-18.

9. Hasła w: Nowy Stownik Teologii Biblijnej (Lublin - Kielce: TN KUL - Wydawnictwo Jedność 2017). 


\section{Recenzja:}

1. „Ocena dorobku naukowego, pracy dydaktycznej i działalności organizacyjnej ks. prof. dr. hab. Romana Bartnickiego", Warszawskie Studia Teologiczne, 31 (2018), 13-21.

\section{Redakcja naukowa:}

1. Nowy Stownik Teologii Biblijnej (Lublin - Kielce: Wydawnictwo Jedność TN KUL 2017).

\section{Sympozja i wykłady:}

1. Udział w pracach Papieskiej Komisji Biblijnej - referat i udział w dyskusji podczas sesji plenarnej 9-13.04.2018.

2. Organizator ogólnopolskiego Pierwszego Narodowego Czytania Pisma Świętego, 15.04.2018.

3. Referat: „Ewangelia Jezusa Chrystusa gwarantem suwerenności narodów” podczas międzynarodowego kongresu „Katolicy i niepodległość - szanse i zagrożenia”, WSKSiM, Toruń, 24-25.11.2017.

4. Przewodniczenie 55. Sympozjum Stowarzyszenia Biblistów Polskich. Legnica, 18-20.09.2017; wygłoszenie referatu.

5. Udział w XIII Międzynarodowych Jesiennych Dniach Biblijnych „The Dead Sea Scrolls Seventy Years Later. Manuscripts, Traditions, Interpretations, and Their Biblical Context", Lublin - KUL, 24-26.10.2017.

6. Udział i referat w Wiosennym Sympozjum Biblijnym 2018 , «Weźmijcie Ducha Świętego» (J 20,22). Duch Święty w Kościele”, Lublin - KUL, 20.03.2018.

7. Udział w XIV Międzynarodowych Jesiennych Dni Biblijnych „«Rosa Twoja jest rosą światłości, a ziemia wyda cienie zmarłych» (Iz 26:19). Zmartwychwstanie w Biblii i kulturze starożytnej basenu Morza Śródziemnego", KUL, Lublin, 23-24.10.2018.

8. Przewodniczenie 56. Sympozjum Biblistów Polskich, Wyższe Seminarium Duchowne, Łomża, 17-19.09.2018.

\section{Promotor pracy doktorskiej:}

1. Ks. Nikos Skuras, Objawienie Piotrowi misji ad gentes (Dz 10-1-48). Studium egzegetyczno-teologiczne (KUL 2018).

\section{Audycje radiowe i telewizyjne:}

1. Telewizyjny Uniwersytet Biblijny (TV Trwam) 
2. „Kościół Mesjasza - Syna Bożego”, 28.01.2017.

3. „Duch Święty - Jego rola w historii zbawienia”, 13.05.2017.

4. „Duch Paraklet - jego rola w Kościele”, 24.06.2017.

5. „Jezus Chrystus - Objawiciel Boga”, 23.06.2017.

6. „Hymn o Logosie (J 1,1-18)”, 11.11.2017.

7. „Jan Chrzciciel - świadectwo o Mesjaszu i Synu Bożym (J 1,19-34)”, 9.12.2017.

8. „Powołanie pierwszych uczniów (J 1,35-51)”, 12.05.2018.

9. „Wesele w Kanie - Mesjasz objawia się Izraelowi”, 13.10.2018.

10. Seria programów TV „Słowo Życia” (TV Trwam).

11. Programy radiowe „Rozmowy niedokończone” i „Szukając Słowa Bożego” (Radio Maryja).

\section{2) Ks. dr Arnold Zawadzki}

\section{Artykuły naukowe:}

1. „Pierwotny Kościół w konfrontacji ze światem pogańskim w świetle pism Nowego Testamentu", Łódzkie Studia Teologiczne 26/3 (2017) 109-144.

2. „Motyw Dnia Pańskiego w Księdze Sofoniasza na tle mesjańskiej radości w So 3,14-17 - perspektywa teologiczna (hamartiologiczna i soteriologiczna)", Collectanea theologica 4 (2017) 41-60.

\section{Publikacja o charakterze duszpasterskim:}

1. Mężnie wyznawać wiarę i postępować wedtug jej zasad-obrzęd bierzmowania $w$ świetle słowa Bożego. Materiały przygotowawcze do Synodu Archidiecezji Łódzkiej na temat duszpasterstwa młodzieży (październik 2017 r.).

\section{Sympozja:}

1. Referat: „Radość Córy Syjońskiej jako współuczestnictwo w mesjańskiej radości Jahwe (So 3,14-17)”, XI Ogólnopolska Konferencja: „Interpretacja Pisma Świętego: Księga Sofoniasza - orędzie, interpretacja i recepcja”, Instytut Nauk Biblijnych, Wydział Teologiczny UKSW, Warszawa, 16.05.2017.

\section{Działalność dydaktyczna:}

Wykłady: „Synoptycy i Pisma Pawłowe”, WSD Łódź oraz Instytut Teologiczny w Łodzi. 


\section{3) Ks. dr Marcin Zieliński}

\section{Artykuły naukowe, hasła słownikowe:}

1. „La morte nel libro della Sapienza. Il rapporto tra la figura della Sapienza e la realtà della morte", The Biblical Annals 7/3 (2017) 307-322.

2. „Uczynki”, Nowy Stownik Teologii Biblijnej (red. H. Witczyk) (Lublin Kielce: TN KUL - Jedność 2017) 913-917.

3. „Uniwersalizm”, NSTB, 918-922.

\section{Sympozja i wykłady:}

1. Organizator: Wiosenne Dni Biblijne 2018, „Weźmijcie Ducha Świętego» (J 20,22). Duch Święty w Kościele”, Lublin (KUL), 20.03.2018.

2. Referat: „Relacja mistrz - uczeń w tradycji mądrościowej i w świecie hellenistycznym”, Duchowość Ziemi Świętej, Lublin (KUL), 26.05.2018.

3. Referat: „«Przyszedł mi z pomocą Duch mądrości» (Mdr 7,7). Duch Święty jako nauczyciel mądrości”, Wiosenne Dni Biblijne 2018 , «Weźmijcie Ducha Świętego» (J 20,22). Duch Święty w Kościele”, Lublin (KUL), 20.03.2018.

4. Wykłady w ramach Telewizyjnego Uniwersytetu Biblijnego (Telewizja Trwam) - 3 wykłady.

5. Wykład w ramach Kursu Formacji Biblijnej - „Piękno Bożej i ludzkiej miłości w Pieśni nad Pieśniami”.

\section{Audycje radiowe i telewizyjne:}

1. Rozważania biblijne w ramach cyklu Szukając Słowa Bożego (Radio Maryja) -3 odcinki.

\section{Działania popularyzujące Biblię:}

1. Organizacja Ogólnopolskiego Konkursu Biblijnego dla Alumnów Seminariów Diecezjalnych i Zakonnych 2018 (4. edycja: 2015, 2016, 2017, 2018) przewodniczący komitetu organizacyjnego oraz komisji egzaminacyjnej.

\section{Szkolenia:}

1. Udział $w$ seminarium translatorskim organizowanym przez Nida Institute - School of Bible Translation w Rzymie (5-9.02.2018) w związku z rewizją Biblii Tysiąclecia, prowadzenie work group. 


\section{Udział w stowarzyszeniach i organizacjach:}

1. Członkostwo w Catholic Biblical Federation (Reprezentant KEP) - wybrany przewodniczącym grupy „Europa Wschodnia i Środkowa”, uczestnik spotkania CBF w Neustift (Włochy).

2. Wybrany zastępcą przewodniczącego Dzieła Biblijnego im. Jana Pawła II na spotkaniu moderatorów (13.01.2018). 